\title{
Rural Livestock Farmers Perception of the Role of Information and Communication Technology Tools in Livestock Production, Management and Improvement in Imo State, Nigeria
}

\author{
Godson-Ibeji, C. C ${ }^{1 *}$, Chikaire, J. $\mathrm{U}^{1}$, Aminu, G. O ${ }^{1}$ \\ ${ }^{\mathrm{T}}$ Department of Agricultural Extension, Federal University of Technology, Owerri, Imo State, Nigeria \\ *Corresponding Author: Godson-Ibeji, C. C \\ Department of Agricultural Extension, Federal University of Technology, Owerri, Imo State, Nigeria
}

\author{
Article History \\ Received: 22.12.2021 \\ Accepted: 30.01 .2022 \\ Published: 28.02.2022
}

\begin{abstract}
The study investigated rural livestock farmers' perception of the roles of Information and Communication Technology (ICT) tools in livestock production, management and improvement in Imo State, Nigeria. The objectives of the study were to identify the various information and communication technology devices used by respondents in the study area, identify the roles of ICT tools in livestock production, management and improvement. Data were collected through questionnaire distributed to 150 ICT-User rural livestock farmers randomly selected from a list of 1500 livestock farmers in Imo State, Nigeria. Percentages, presented in frequency distribution tables, mean score were used to analyze the data. Results showed that the ICT tools available to the rural livestock farmers include mobile phones (91.3\%), radio $(56.6 \%)$, television $(61.3 \%)$ and the internet $(60 \%)$. With an acceptable mean score of 2.50 , ICT tools play vital roles in livestock production, management improvement. Such roles includes reduced cost of production $(\mathrm{M}=2.80)$, facilitate livestock health care $(\mathrm{M}=3.31)$, track whereabout of animals $(\mathrm{M}=2.90)$, provision of technical advice $(\mathrm{M}=3.10)$, information on feeds/feeding $(\mathrm{M}=2.80)$, record keeping $(\mathrm{M}=2.80)$, forecast incidence of diseases $(\mathrm{M}=3.41)$, among other roles. The above underscores the importance of information in animal agriculture and the business of farming in general.
\end{abstract}

Keywords: ICT, livestock, management, farmers, production.

\section{INTRODUCTION}

Agriculture is a significant element of Nigeria's economy, with livestock playing an important role. Increased food production, farm energy, manure, fuel, transportation, nutritional security, an incomes are all benefits of livestock farming in both urban and rural populations (Tewe, 1997). Livestock accounts for one third of Nigeria's agricultural gross domestic product (GDP). In 2010, livestock production contributed substantially to Nigeria's economy, accounting for about $11 \%$ of the total GDP (Encyclopedia of the Nation) The year 2010 was a good year for livestock production.

Livestock systems cover over $30 \%$ of the planet's ice free terrestrial surface area and are a valuable global asset worth at least $\$ 1.4$ trillion (Steinfeld and colleagues, 2006). Long market chains in the livestock sector employ at least 1.3 billion people worldwide and directly support the livelihoods of 600 million poor smallholder farmers in developing countries (Thornton et al., 2006). Poor farmers, consumers, traders, and laborers all over the developing world rely on livestock to maintain their livelihoods. Enhancement of livestock production systems has the biggest influence on sustainable development aimed at helping the disadvantaged. Animal diseases are a major stumbling block: poor people's animals are particularly susceptible to disease due to the high cost, lack of, or unsuitability of animal health and production input (FAO, 2010). Livestock farming is a vital aspect of the national economy as well as the economics of states and municipalities.

The production of livestock, as well as other commodities, has a ripple effect throughout the economy, resulting in jobs, production in allied industries, taxes paid to local, state, and federal governments, indirect impacts from input sup ply purchases, and induced impacts from household spending across the state. Nigeria's cattle industry accounts for the $\mathrm{m}$

Copyright () 2022 The Author(s): This is an open-access article distributed under the terms of the Creative Commons Attribution 4.0 International License (CC BY-NC 4.0) which permits unrestricted use, distribution, and reproduction in any medium for noncommercial use provided the original author and source are credited. 
ajority of the country's total livestock cash income. It has contributed an average of $12 \%$ of total Nigerian livestock cash $\mathrm{i}$ ncome during the last decade (NBS 2010). Inspite of all this livestock production has not been taken seriously as part of the contributor to Nigeria economy as it is supposed to be and this has led to the study. One major factor here is the lack of information and proper knowledge base of the farmers. The use of modern information tools becomes necessary. ICT therefore presents itself as the solution.

ICT could assist Nigerian farmers in efficiently accessing and disseminating current information. Joining online farmer groups, advertising in local farmers markets that may host a neighborhood website, and joining social network sit es like Facebook to build community interest in the farmer's activities are all examples of innovative ways to reach out to buyers and customers (Jones 1997). Farmers can use their savings in a variety of ways thanks to ICT, with many reinvest ing extra cash in their enterprises or paying for their children's schooling (Jama, Stuth, Kaitho, Hurissa, 2004).

In Nigerian communities, ICT deployment in livestock is expected to be fragmented and ligh, with disparities based on the level and quality of telecommunication services, individual ability and demographic characteristics, and the scale of enterprises with which those individuals are affiliated, among other factors. Farmers who are well-educated or involved in large scale farming, for example, are more likely to use ICT than others.

Farmers might also use mobile phones and other forms of ICT to notify clients about product availability or to discuss and negotiate rates. Many farmers live far away from their farms and may need to communicate with individuals in charge of them on a frequent basis to keep up with farm conditions. In terms of education, farmers might learn how to manage farms, manufacture feeds, and handle infections and other issues by doing so, surfing the web or connecting with their veterinarian, fellow farmers, and others.

The potential benefits of ICT to farmers and farm processes call for need to understandfactors that might influence the use of the technologies by farmers. Similar studies exist ((Kiplang'at, 1999; Heeks, 1999; Bayes, 2001; Dao, 2004), but there is none on Ibadan city, an agrarian and largest semi urban community in West Africa.

However, interactions with agricultural extension workers and agro-based entrepreneurs as well as literature sources (Agwu and Uche-Mba, 2010) show that cost of the technology, lack of training, trust level in ICT, lack of ICT proficiency, lack of technological infrastructure and non-awareness and unwillingness to use new technologies could be influencers of use of ICT by farmers in many Nigerian communities.

This evidence emanates mainly from general observations, with a few studies based on the opinions of farmers who are directly involved with the use of the ICT. Furthermore, there are no streamlined studies that show how relevant these general factors are to livestock farming in any Nigerian community with their unique agricultural processes and demands.

This study was designed to examine ICT tools used in livestock production in Imo State, Nigeria and the vital roles the tools play in improving livestock farming generally.

\section{Methodology}

Imo State is made up of twenty seven (27) Local Government Areas. It lies within longitude 6'50E to 3.3SE and latitude $4^{\prime} 30 \mathrm{~N}$ to $6{ }^{\prime} 30 \mathrm{~N}(\mathrm{IMSG}, 2000)$. The state is divided into three Agricultural zones namely Okigwe, Owerri and Orlu (ADP, 2003). It lies within the tropical rain and evergreen forest with a tropical climate that is humid all year round. The rainy season spans from March to October and bimodal with a two week break (in rainfall) in August. The main annual temperature is between $50 \%$ and $60 \%$ during the dry season. The major arable crops grown are cassava, yam, plantain/banana, maize, melon, sweet potato and vegetable such as telfera, okro, pepper and tomatoes, Farm holdings in Imo State ranges from 0.3 has to 1.0 ha (ADP, 2003). The two main source of data were used in this study namely, Primary and secondary sources. Primary data were obtained from the field investigation while secondary were obtained from textbook, internet, journals, information from library etc. Purposive sampling technique was used in selecting the sample for this study. All ICT-user rural livestock farmers in Imo State constituted the population of the study. A list of 1500 ICT-user rural livestock farmers was obtained from Agricultural Development Programme in (ADP) office in Owerri, the State capital. From this list, a total sample size of 150 ICT-user rural livestock farmers was selected. Data was analyzed using descriptive statistical tools such as percentages presented in tabular forms and mean. This was used to analyze objectives 1 of the study. Objective 2 was achieved on a 4-point Likert type scale of Strongly agree (SA), Agree (A), Disagree (D), and Strongly disagree, assigned score of $4=3=2=1$. This was divided by 4 to give a discriminating mean index of 2.50 as the acceptable score. It is specified mathematically as $4=3=2=1=10 / 4=2.50$ 


\section{RESULTS AND DISCUSSION}

\section{Information and Communication Technology Devices Used}

Table 1 showed that $91.3 \%$ of the respondents own and make use of mobile phones to share, obtain, disseminate and transfer information. 56.6 percent of the respondents make use of radio, 61.3 and 41.3 percent respectively use TV and newspapers. It can also be seen that laptops, digital camera and CD-ROMS are not widely used by the respondents as only 37.3, 14 and 16.6 percent were aware of such ICT devices. This implies that information can easily be transferred among respondents as the information and communication technology devices are common in the area. These data support Mundi's (2011) assertion that, despite the fact that mobile phones are versatile gadgets, voice calls still reign supreme, particularly in rural areas. Aside from that, farmers prefer voice calls over other mobile phone services. Because voice communication is the most fundamental function, it just necessitates a basic level of literacy (Ahmed and Lurent, 2009).

ICTs have become more incorporated into the broadcast of agricultural information throughout Africa, accordin g to Gakuru et al., (2009). Traditional types of ICTs, such as radio and television, have grown more common in the provi sion of advisory services through producing agricultural-related programs. Farmers also cited cost effectiveness and timeliness (immediacy) as reasons for using phone calls, which mainly aligns with Mittal and Tripathi's (2009) beliefs that communication expenses can be reduced by using voice calls. Farmers can have access to timely, high-quality information by using mobile phones. Without a doubt, farmers who use mobile phones save transportation costs, time, and reduce the perishability of some farm produce, which is unquestionably important in agribusiness. Many crops are extremely time-sensitive, so farmers who use mobile phones save money, time, and reduce the perishability of some farm produce (Muto and Yamano 2009).

Table 1: Information and communication technology devices used

\begin{tabular}{|l|l|l|}
\hline ICT devices used & *Frequency & Percentage (\%) \\
\hline Mobile phone & 137 & 91.3 \\
\hline Television & 92 & 61.3 \\
\hline Radio & 85 & 56.6 \\
\hline Internet & 90 & 60.0 \\
\hline Newspaper & 62 & 41.3 \\
\hline Digital camera & 21 & 14.0 \\
\hline CD. ROMS & 25 & 16.6 \\
\hline Laptop & 56 & 37.3 \\
\hline
\end{tabular}

*Multiple responses

\section{Perceived Roles of ICTs in Livestock Production}

Table 2 showed the perceived roles of information and communication technologies in livestock production. These include; to reduce the cost of livestock production $(M=3.22)$, to facilitate livestock health management $(M=3.31)$, data base storage used in artificial insemination $(M=3.21)$, to channel information to consumers who are difficult to reach $(\mathrm{M}=2.9)$, to include small holders in supply chain $(\mathrm{M}=2.9)$, to enable two way communication with livestock experts $(\mathrm{M}=3.0)$ to checkmate and information on disease $(\mathrm{M}=3.4)$, to monitor vaccination schedules in livestock production $(M=3.1)$ and to get rid of various animal diseases $(M=3.2)$. However, the respondents did not agree that information and communication technologies help to monitor animal disease and surveillance $(\mathrm{M}=2)$.

The main advantage of using a mobile phone is that it may be utilized as a platform for exchanging information via phone calls, SMS messages, or even the Internet. The adoption of mobile phones increases access to information whil e also lowering the cost of obtaining it (Overa, 2006). Unlike the traditional method of agricultural extension, new agricu ltural practices such as soil preparation and planting, irrigation and weeding methods, cultivation, harvesting, and storage methods can be sent to farmers via text messages or voice calls on their mobile phones, rather than traveling to their loca tions to deliver face-to-face teachings (Aker, 2008).

Substituting phone calls for travel improves safety while also saving time, money, and the perishability of farm goods for farmers (Muto and Yamano 2009). In terms of cost, geographic coverage, and convenience of use, mobile phon es are the sole "accessible device" compared to other options (Aker and Mbiti, 2010). 
Table 2: Perceived Roles of ICTs in livestock Production

\begin{tabular}{|l|l|l|l|l|l|}
\hline Roles of ICT & SA & A & D & SD & Mean \\
\hline To reduce the cost of livestock production & 94 & 13 & 20 & 17 & 3.22 \\
\hline To facilitate livestock health management & 57 & 83 & 9 & 6 & 3.31 \\
\hline Database storage used in artificial insemination & 63 & 71 & 10 & 1 & 3.31 \\
\hline To channel information to consumers who are difficult to reach & 36 & 85 & 20 & 9 & 2.93 \\
\hline To include small holders in supply chain & 71 & 17 & 42 & 20 & 2.92 \\
\hline To enable two way communication with livestock experts & 48 & 72 & 20 & 10 & 3.01 \\
\hline To checkmate and provide information on diseases & 61 & 85 & 3 & 1 & 3.41 \\
\hline Monitor vaccination schedules in livestock production & 51 & 71 & 20 & 8 & 3.10 \\
\hline Monitor animal diseases and surveillance & 22 & 100 & 37 & 26 & 2.21 \\
\hline Animal diseases diagnosis & 34 & 99 & 9 & 1 & 3.1 \\
\hline To get rid of various animal diseases & 64 & 62 & 14 & 10 & 3.2 \\
\hline
\end{tabular}

Accepted mean $=2.50$

\section{Roles of ICT in livestock management}

Table 3 reveals that ICT tools play the following roles in livestock management; to track whereabouts/location of animals $(\mathrm{M}=2.9)$, provision of technical advice $(\mathrm{M}=3.1)$, improved management of data and information $(\mathrm{M}=3.1)$. ICT tools are used in animal health breeding $(\mathrm{M}=3.31)$, diary hard management $(\mathrm{M}=3.22)$ provide information on feed/feeding $(M=2.80)$, provide farmers with valuable source of reference $(M=2.88)$, set-up productivity benchmark $(\mathrm{M}=2.70)$, animal vaccination management $(\mathrm{M}=2.63)$, act as advisory service in livestock management $(\mathrm{M}=3.1)$, it facilitate payment online for livestock products $(\mathrm{M}=3.10)$.

ICTs may be a powerful tool for communicating massive volumes of useful information to communities about markets, technologies, prices, successful experiences, credit facilities, government services and regulations, weather, crop, livestock, and natural resource protection. Knowledge and information gained can have a significant impact on agricultural production and food security. interventions and increasing agricultural productivity. Media such as the Internet, web-based means, mobile telephony and computer-mediated networks among others are being used in a number of initiatives in Africa to provide development solutions interventions and increasing agricultural productivity. Media such as the Internet, web-based means, mobile telephony and computer-mediated networks among others are being used in a number of initiatives in Africa to provide development solutions (Girard, 2003; Munyua, 2008). Modern ICTs have the potential to play a significant role in communicating knowledge and information to agricultural communities, delivering education modules, gaining access to inputs, markets and market prices, credit, conducting business, facilitating networking and strengthening partnerships, and scaling up development interlinkages.

Table 3: Perception of roles of ICT in livestock management

\begin{tabular}{|l|l|l|l|l|l|}
\hline Roles of ICT & SA & A & D & SD & Mean \\
\hline Track whereabouts of animals & 49 & 56 & 25 & 20 & 2.9 \\
\hline Provision of technical advice & 51 & 71 & 18 & 10 & 3.10 \\
\hline Improved management of data and information & 62 & 56 & 14 & 18 & 3.12 \\
\hline Animal health and breading & 72 & 61 & 9 & 8 & 3.31 \\
\hline Telemedicine & 38 & 53 & 26 & 33 & 2.64 \\
\hline Gene mapping and development of new breeds & 42 & 63 & 19 & 26 & 2.81 \\
\hline Diary herd management & 76 & 48 & 10 & 16 & 3.22 \\
\hline Provide information on feed/feeding & 53 & 38 & 33 & 26 & 2.80 \\
\hline Provide farmers with reliable source of reference & 60 & 40 & 22 & 28 & 2.88 \\
\hline Set up productivity benchmark & 38 & 50 & 48 & 14 & 2.7 \\
\hline Animal vaccination management & 45 & 38 & 41 & 27 & 2.6 \\
\hline To develop models for better management & 40 & 26 & 38 & 46 & 2.4 \\
\hline To act as an advisory service in livestock management & 68 & 43 & 18 & 21 & 3.1 \\
\hline It facilitate payment online for livestock products & 70 & 47 & 13 & 20 & 3.11 \\
\hline
\end{tabular}

Accepted mean $=2.50$

\section{Roles of ICT in Livestock Improvement}

Table 4 reveals the following roles of information and communications technologies in livestock improvement; to store genetic information of animals $(M=2.9)$, increased income from production to keep record of individual animal $(\mathrm{M}=3.0)$, act as notification to task or as reminder $(\mathrm{M}=2.8)$, to forecast incidence of disease $(\mathrm{Mean}=2.5)$, help in transporting breeding material $(\mathrm{M}=2.8)$, to keep data on livestock resources (mean=3.4), to keep time schedule in livestock farming $(M=2.7)$, facilitate production of quality and healthy livestock (mean=3.0), aids in technology 
dissemination $(M=3.2)$, gives insight on the control of parasitic and infectious diseases around $(M=2.7)$, reduce the energy utilization and stress there in $(M=3.0)$, help farmers connect and sell their products $(M=3.1)$ help farmers make choice about livestock $(M=2.9)$ increase the performance of farm animal $(M=3.0)$, timeliness of sale of livestock products $(M=3.0)$, increase income from production $(M=3.2)$. Nevertheless, the respondents didn't agree that ICT helps farmers to increase their bargaining power (mean $=2.4$ ).

Everything is connected in the digital world, including farming and agriculture. Livestock technology can help increase or improve animal and livestock productivity, welfare, and management. As more dairy herds are linked with sensors to monitor health and boost output. There is the concept of the "connected cow" (Taylor \& Ku, 2019). Individual wearable sensors on cattle can measure daily activity and health issues while also offering data-driven insights for the whole herd. All of this data is being transformed into useful, actionable insights for producers to look at quickly and easily in order to make timely management decisions.

Table 4: Perceived role of ICT in livestock improvement

\begin{tabular}{|c|c|c|c|c|c|}
\hline Roles of ICT & SA & $\mathrm{A}$ & D & SD & Mean \\
\hline Store genetics information of animals & 43 & 62 & 29 & 16 & 2.9 \\
\hline Increased income from production & 52 & 63 & 15 & 20 & 3.0 \\
\hline To keep record of individual animal & 48 & 54 & 26 & 22 & 2.8 \\
\hline Act as notification to task or reminder & 38 & 43 & 39 & 30 & 2.5 \\
\hline To forecast incidence of disease & 76 & 61 & 11 & 2 & 3.4 \\
\hline Help in transporting breeding material & 53 & 43 & 37 & 17 & 2.8 \\
\hline To keep data on livestock resources & 73 & 45 & 21 & 11 & 3.2 \\
\hline To store information on the population of livestock & 47 & 68 & 13 & 22 & 2.9 \\
\hline To keep time schedule in livestock farming & 38 & 53 & 38 & 21 & 2.5 \\
\hline Facilitate production of quality and healthy livestock & 63 & 43 & 26 & 18 & 3.01 \\
\hline Aids in technology dissemination & 76 & 48 & 17 & 9 & 3.2 \\
\hline $\begin{array}{l}\text { Gives insight on control of parasite and infectious } \\
\text { disease around }\end{array}$ & 50 & 38 & 42 & 20 & 2.7 \\
\hline Reduce the energy utilization and stress therein & 61 & 48 & 32 & 9 & 3.0 \\
\hline Help farmers connect/sell their products & 72 & 42 & 28 & 8 & 3.1 \\
\hline Increase farmer bargaining power & 38 & 53 & 38 & 21 & 2.5 \\
\hline Help me farmers make choice about livestock products & 60 & 38 & 36 & 16 & 2.9 \\
\hline Increased performance of farm animal & 62 & 47 & 27 & 14 & 3.0 \\
\hline Timelines of sale of livestock products & 53 & 55 & 33 & 9 & 3.0 \\
\hline Increased income from production & 71 & 46 & 21 & 12 & 3.2 \\
\hline
\end{tabular}

Accepted mean $=2.50$

\section{CONCLUSION}

The result showed that the farmers can ascertain the role of information and communications technologies in livestock production, management and improvement. Information and communication technologies help livestock experts to exchange and share ideas among themselves. It also helps them to transfer information to non-livestock farmers to aid in the marketing of their products. These information and communications technologies created for the livestock farmers to acquire mere knowledge about information and communications technology.

\section{REFERENCES}

- Agwu, A. E., Uche-Mba, U. C., \& Akinnagbe, O. M. (2008). Use of information communication technologies (ICTs) among researchers, extension workers and farmers in Abia and Enugu states: Implications for a National Agricultural Extension Policy on ICTs. Journal of Agricultural Extension, 12(1), 37-49.

- Ahmed, T. R., \& Laurent, E. (2009). Mobile phones and development: An analysis of IDRC-supported projects. Electronic Journal on Information Systems in Developing Countries, 36(2), 1-16. Retrieved 27 May, 201 from http://www.ejisdc.org/ojs2/index.php/ejisdc/article/viewFile/529/265

- $\quad$ Aker, J. C. (2008). Does Digital Divide or Provide? The impact of mobile phones on grain markets in Niger Center for Global Development Working Paper No. 154. Available at http://www.cgdev.org/content/publications/detail/894410]

- Aker, J. C., \& Mbiti, I. M. (2010). Mobile phones and economic development in Africa center for global development working paper No. 211, pp. 1-44. Available at http://www.cgdev.org/files/1424175_file_Aker_Mobile_wp211_FINAL.pdf

- $\quad$ Bayes, A. (2001). Infrastructural and rural development: insights from a Grameen Bank village phone initiative in Bangladesh. Agricultural Economics, 25, 261-272. 
- Dao, M. Q. (2004). Rural poverty in developing countries: an empirical analysis. Journal of Economic Studies, 31(6), 500-508.

- FAO. (2010). Food and agriculture organization of the United Nations statistical databases http://faostat.fao.org [4].

- Gakuru, M., Winters, K., \& Stepman, F. (2009). Inventory of Innovative Farmer Advisory Services using ICTs, For: The Forum for Agricultural Research in Africa (FARA). www.faraafrica.org/.../Innovative_Farmer_Advisory_Systems.pdf retrieved on 3rd March, 2011

- Girard, B. (2003). The one to watch: Radio, New ICTs and interactivity, Food and Agriculture Organization of the United Nation, Rome.

- Heeks, R. (1999). Information and Communication Technologies, Poverty and Development, Development Informatics Working Paper, available at: http://www.sed.manchester.ac.uk/idpm/research/publications/wp/di/di_wp05.htm, accessed on 23/03/2007

- Jama, A., Stuth, J., Kaitho, R., \& Hurissa, B. (2004). Innovative ICT Approaches for Pastoral Livestock Development: A New Proposal for a Unified Livestock Information System in Ethiopia: Proceedings of Ethiopian Association for Animal Production. ESAP Proceedings, 69.

- Jones, G. E. (1997). The History Development and Future of Agricultural Extension. In Swanson, B. F. (ed) Improving Agricultural Extension A Reference Manual. Food and Agriculture Organization, Rome.

- NBS. (2010) Nigeria Livestock Industry, 2010. National Bureau of Statistics, Abuja, Nigeria.

- Mittal, S., \& Tripathi, G. (2009). Role of mobile phone technology in improving small farm productivity, Agricultural Economics Research Review, 22, 451-459.

- Mundi, I. (2011). Kenya Literacy [Retrieved 23rd May, 2015 from http://www.indexmundi.com/kenya/literacy.html]

- Munyua, H. (2008), Final Report. ICTs and small-scale agriculture in Africa: a scoping study, Report prepared on behalf of the International Development Research Centre (IDRC). http://ideas.repec.org/p/iim/iimawp/2005-1104.html retrieved on 30th September, 2009

- Muto, M., \& Yamano, T. (2009). The impact of mobile phone coverage expansion on market participation: Panel data evidence from Uganda. World Development, 37(12), 1887-1896.

- Overa, R. (2006). Networks, distance and trust: Telecommunications development and changing trading practices in Ghana World Development, 34(7), 301-315.

- Steinfeld, H. (2006). Livestock's long shadow: environmental issues and options. Rome, Italy: FAO [9].

- Thornton, P. K. (2006). Mapping climate vulnerability and poverty in Africa. Nairobi, Kenya: ILRI; retrieved from http://www.dfid.gov.uk/research/mapping-climate.pdf on 1/12/2016

- $\quad$ Tewe, O (1997). World livestock poultry system (internet) http//.poultrysite,com. Accessed 28th November 2011.

- Taylor F., \& Linly, K. (2019). Livestock Farming Technology in Animal Agriculture. Available at https://www.plugandplaytechcenter.com > resources > live. 